\title{
Research on Chinese Intelligent Guanglianda in High-rise Construction
}

\author{
Marina Romanovich ${ }^{1}$, Peiyu $\mathrm{Shi}^{1,2}$,Ziyue Wang ${ }^{1,3}$, Liang Zhao ${ }^{4, *}$, and Vera Gerasimova ${ }^{5}$ \\ ${ }^{1}$ Peter the Great St. Petersburg Polytechnic University, 195251, Polytechnicheskaya, St.Petersburg, \\ 29, Russia \\ ${ }^{2}$ Institute of Civil Engineering, China University of Mining and Technology, No.269, Liberation \\ south road, Xuzhou, Jiangsu, China \\ ${ }^{3}$ Institute of Civil Engineering, Southwest Jiaotong University, No. 111, North $1^{\text {st }}$ Section of Second \\ Ring Road, Jinniu District, Chengdu, Sichuan, China \\ ${ }^{4}$ Civil Engineering Department, Xi'an Jiaotong University, 28 Xianning West Road, Xi'an, Shaanxi, \\ China \\ ${ }^{5}$ Moscow State University of Civil Engineering, Yaroslavskoe shosse, 26, Moscow,129337, Russia
}

\begin{abstract}
Since the reform and opening up in China, the rapid development of China's construction industry, especially after 2011, BIM technology in China has a rapid development and depth of application. This article mainly discusses the process of development of China's construction industry management and the process of development of BIM technology in China and, the use of software in China, the main use of revit in 3D modeling (design stage), the use of Guanglianda in the whole process of construction management. This article researches on Guanglianda and the applications were described, for example, in the integrated project of management information, labor management information, construction video surveillance, material management, material site acceptance. This paper also elaborates on the cooperation of Revit and Guanglianda in different stages. This paper also elaborates on a construction case in China, and makes a description of the problems of crane, facts and time, and then explores the reasons behind the rapid construction of China. And the feasibility of China's construction management approach to the introduction of Russia.
\end{abstract}

\section{Introduction}

The introduction and development of BIM technology in China has gone through three stages. The first stage is the concept introduction stage (1998-2005). This stage is mainly due to the introduction of IFC standard. In 1998, Chinese industry researchers began to contact and study IFC Standard, and in 2002 China Academy of Architecture hosted the "IFC standard technology seminar", China's construction industry according to their own situation on the IFC standard in the practical application of the project were studied and expanded[1]. The second stage is the theoretical research and preliminary application stage (2006-2010),

*Corresponding author: luke1996@stu.xjtu.edu.cn 
BIM at the stage of the concept has been a preliminary understanding of scientific research institutions for BIM technology becoming a theoretical study, in 2010,

Tsinghua University and Autodesk joint development BIM technology has also begun to pilot applications in high-end complex demonstration projects, such as the Shanghai World Expo project, the Shanghai Bund SOHO project, etc. BIM technology in the "China BIM standard framework research", proposed the establishment of China Building Information Model Standards, CBIMS. China in the design stage from the application to the construction process for the whole process of expansion of the trend, in 2008 the world's third high-rise Shanghai Center project in the BIM technology: curtain wall and steel structure design, professional collision inspection, engineering calculation, construction simulation aspects of the application, but the software is still dominated by foreign software, such as revit. The development of BIM in china shown in fig1.

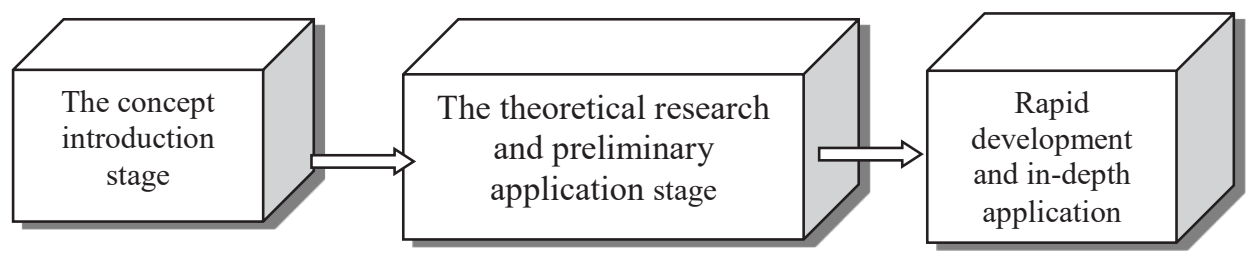

Fig. 1. Development of BIM in China.

(2011 - present), China's national policy clearly put forward the development of BIM to support, in 2011 China's Ministry of Housing and Urban and Rural Development issued (2011-2015) construction information Development plan, the BIM included in the "second five" key promotion technology, China's governments at all levels are also actively promoting the application of BIM, BIM's technical research work is also included in the national subject, the relevant national standards have entered the preparation stage, the current BIM technology in the project mainly presents the following characteristics: firstly, enterprise application BIM technology project scope is expanding, $43.3 \%$ of enterprises in the project has started using BIM technology[2,3] . BIM application is more and more, and gradually achieve the whole professional, the whole process of BIM collaborative design. BIM technology is applied not only to the design stage of use, but also widely applied in the engineering calculation, construction simulation, depth design, professional coordination and progress control, based on 4D $(3 \mathrm{D}+\operatorname{cost})[4], 5 \mathrm{D}(3 \mathrm{D}+$ cost + progress $)$ of the overall construction project management solutions are also implemented in a number of large projects[5]. China's own BIM application software is also a large number of practical projects, such as Guanglianda, luban and so on. In general, BIM technology is the depth of the application of the typical "BIM +", that is, BIM technology as the core of the threedimensional information management system[6-7].

The Construction organization plan is the product of economic system. Before the $1970 \mathrm{~s}$, Chinese construction enterprises are under the planned economy system, they were insufficient recognition of the construction organization plan, they took construction organization plan as a technical document with the single function. In the 1980s, with the development of market economy, the construction organization plan was constantly changing its character, construction organization plan including the project management functions. Nowadays, with China joining into the WTO, the Guanglianda which is based on BIM become a tendency of future design and construction development, it puts forward new requirements for the optimization of construction organization plan. The development process of construction organization plan is shown in Table 1. 
Table 1. Development process of construction organization plan.

\begin{tabular}{|c|c|}
\hline Time & Event \\
\hline 1951 & Chinese first batch of key industrial projects \\
\hline 1953 & Ministry of Water Resources promulgates "Notice on Construction \\
Organization Plan"
\end{tabular}

After 2011, with the use of Guanglianda, the construction organization plan has been further optimizing, Chinese construction industry ushers in a faster development. According to the data of "Ministry of Housing and Urban-Rural Development of the People's Republic of China" and "National Bureau of Statistics of the People's Republic of China", we can get the development situation of construction industry in China. Fig2 is the development of builtup area in China and fig3 is Gross output value of construction in China.

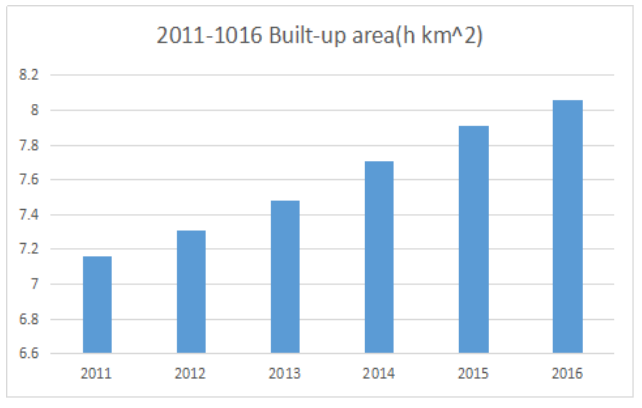

Fig. 2. 2011-2016 The development of built-up.

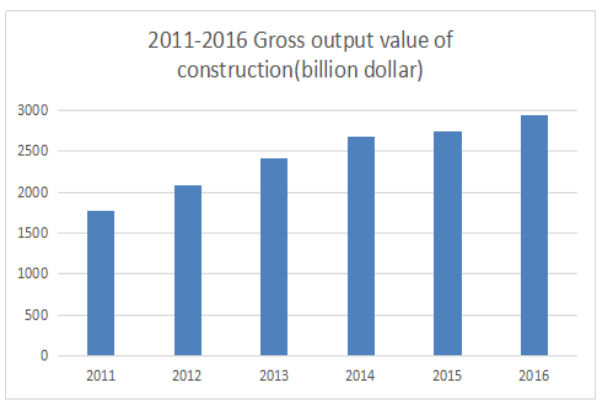

Fig. 3. 2011-2016 Gross output value of construction in China.

\section{Methods}

\subsection{PM methods}

According to China (unified standard for buiding information modeling)[8], BIM5D technology covers from the design, cost, construction, project operations and other aspects to achieve all aspects of the precise cost management. And the definition of BIM5D, 1D is hand drawing, 2D can be understood as electronic drawing, 3D is 3D simulation, 4D is in 3D on the basis of the simulation, we add the time dimension. In order to plan the feasibility of the project and optimize the construction task, the 5D is the cost factor added on the basis of $4 \mathrm{D}$, and the calculation process is done for the construction of the project. Cost, improve the quality, shorten the duration. On June 16, 2015, China was promulgated by the Ministry of Housing and Construction (on the guidance of advancing the application of building information model). The construction of the project was marked by laws and regulations, and 
the technology was marked as a bureau, and the application of BIM was popularized and deepened in the construction field. Construction management cover mainly in the following aspects:

\section{1) Coordination management}

A project construction often has a lot of units involved, so in coordination of various units, improving the ability to exchange information is particularly important, BIM5D technology for all information are integrated and digital management, optimizing the site construction environment and allocating resources, reducing the construction site of the participants.

\section{2) Cost control}

The best performance of BIM5D technology in the cost control is the dynamic cost management, according to the progress of changes in cost control tracking and reviewing, the rapid formation of the project cost plan, in the construction simulation according to the construction schedule which can find the corresponding cost percentage, if expected cost is found more then that of the total cost, you can immediately modify the schedule and construction mode, the loss will be reduced to a minimum stage.

\section{3) Progress control}

BIM5D technology is based on BIM construction model, including integrated management of participants and professional schedule, comprehensive and dynamic grasp of construction progress, solving the conflict and contradiction between construction and resource allocation, based on the three main factors of resources, cost, material, in advance, things, and after the control, making the construction schedule to optimize the process, to ensure the completion of the task. 3D Module of typical floor with Guanglianda(GCL) is shown in fig4 .

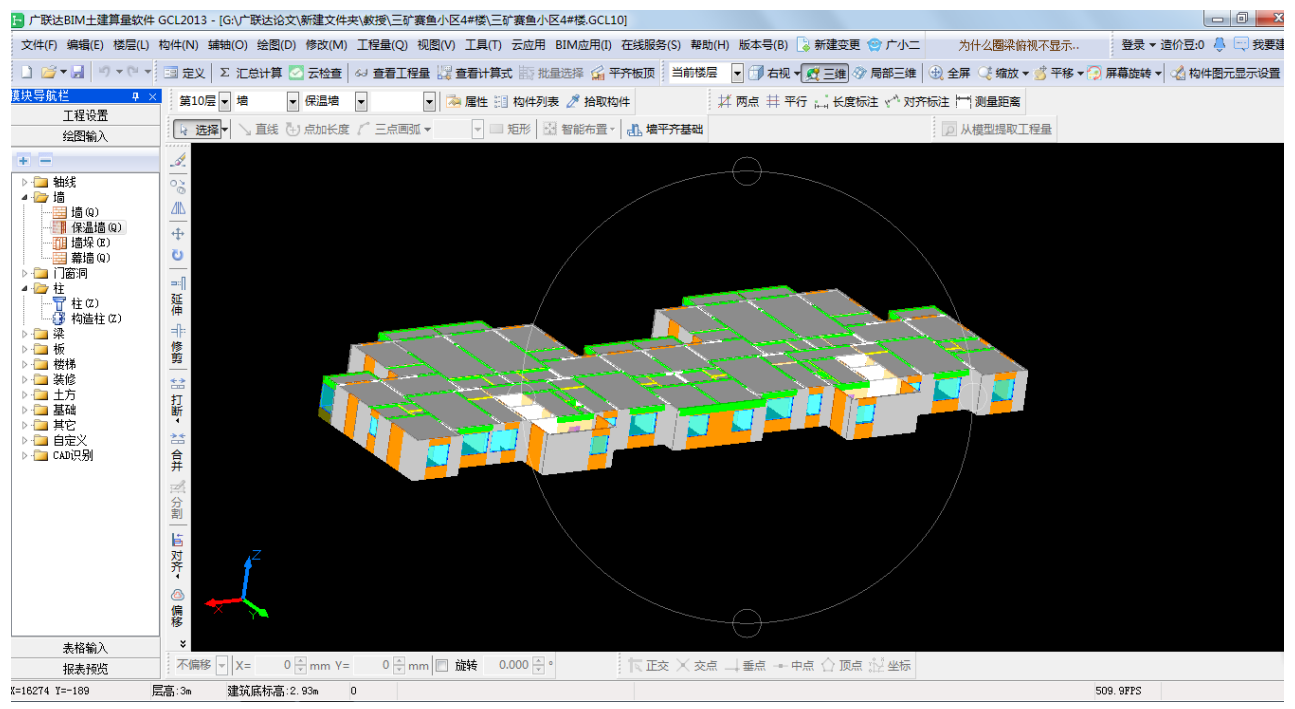

Fig. 4. 3D Module of typical floor with Guanglianda (GCL)

4) Quality control 
Quality control follows the principle of PDCA cycle through the planning, implementation, inspection, processing to start the control, for the complex construction process of digital simulation, to achieve three aims of lofting, positioning and detection, to achieve remote quality testing which can carry out construction, equipment and other professional and pipeline in the construction of the various stages of the collision detection, analysis and simulation, good pre-control, reduction of reworking.

\section{5) Document management}

The construction of each data is the basis of post-query. BIM completion model can include engineering start, project planning, project implementation, engineering control, project accomplishments of the whole process of information data which increases the data accuracy and provides the decision-makers with the guiding role during the late operation and management.

\subsection{Navisworks and Guanglianda}

Autodesk Navisworks software can combine the data of AutoCAD or Revit design with the geometry and information from other design tools, we usually consider it as the whole threedimensional project it is reviewed by a variety of real-time formats. Navisworks software products can help all related project to be a whole, so as to optimize design from the decisionmaking, implementation, performance prediction and planning to the facility management and operation stage[14].

Autodesk Navisworks software includes three kinds of products, which can help us to strengthen the control of the project, it can also improve work efficiency even in the most complex projects to ensure the engineering quality.

1. Autodesk Navisworks Manage software is a comprehensive review solution, it is used by design and construction management professionals to ensure the smooth progress of the project.

2. Autodesk Navisworks Simulate software can accurately reproduce the design intention, make accurate four-dimensional construction schedule, and realize the visualization of construction projects,

3. Autodesk Navisworks Freedom is a browser, it is free to view all the engineering drawings of Navisworks Review, Navisworks Simulate or Navisworks Manage. Navisworks Freedom provides design professionals with efficient communication methods to enable them to review the NWD format's project files in a convenient, secure and smooth manner.the comparison between Navisworks and Guanlianda shown in table2.

Table 2. Comparison between Navisworks and Guanglianda.

\begin{tabular}{|c|l|l|}
\hline Name & \multicolumn{1}{|c|}{ Navisworks } & \multicolumn{1}{c|}{ Guanglianda } \\
\hline & -NWD and 3D & Different functional parts: \\
& DWF Publishing & GLM: \\
& -Collaboration & -Advanced Technological Platform \\
& Toolkit & -Advanced product management system letting \\
Features and & -Photorealistic & -Strong customization capability \\
Speciality & Visualization & GJK: \\
& -Object Animation & -Labor management network \\
& -4D Scheduling & -Real-time management \\
& -Clash and & GLK: \\
& Interference & -Automatic risk warning and risk management \\
& Detection & -Multidimensional analysis and problem tracing system \\
\hline
\end{tabular}




\begin{tabular}{|l|l|l|}
\hline & - Clash and & GBQ: \\
Interference & -Efficient and comprehensive pricing \\
Management & -Convenient group price; \\
· Real-Time & -Fast report processing; \\
Navigation & -Automatic bid management \\
\hline
\end{tabular}

Guanglianda`s application functions mainly include: GLM, GJK, GLK, GBQ, the following table 3 to explain these basic functions, but also a brief overview of the core advantages.

Table 3. Basic function and core-advantages of Guanglianda.

\begin{tabular}{|c|c|c|}
\hline Function & Description & Core-advantages \\
\hline GEPS & $\begin{array}{l}\text { - Guanglianda of construction } \\
\text { enterprises project management } \\
\text { information solution GEPS is designed } \\
\text { for the business input to the } \\
\text { construction process of the whole } \\
\text { process of management as the main } \\
\text { line. } \\
\text { - Focusing on the construction business } \\
\text { core value chain; } \\
\text { - Running through the upstream and } \\
\text { downstream industry chain of } \\
\text { management product platform to help } \\
\text { enterprises to enhance the intensive } \\
\text { management and project management } \\
\text { level. }\end{array}$ & $\begin{array}{l}\text { - Technology platform: a strong } \\
\text { organizational structure, workflow, } \\
\text { statements, instant messaging, } \\
\text { integration and other capabilities; } \\
\text { - Advanced product management } \\
\text { system letting customers enjoy the } \\
\text { benefits of continuous product } \\
\text { upgrades; } \\
\text { - Providing the overall solution for } \\
\text { project management, all the project } \\
\text { management products can be a perfect } \\
\text { integration. } \\
\text { - A strong customization capability, } \\
\text { customers can choose the most } \\
\text { efficient, most stable, the highest } \\
\text { quality customization service. }\end{array}$ \\
\hline GLM & $\begin{array}{l}\text { - Guanglianda GLM labor management } \\
\text { system at construction site. } \\
\text { - Focusing on the construction } \\
\text { enterprises to enhance the project } \\
\text { management capability; } \\
\text { - Committing to the enterprise } \\
\text { management centralized and } \\
\text { standardized construction. }\end{array}$ & $\begin{array}{l}\text { - The use of internet technology } \\
\text { connects the independent components. } \\
\text { - Composing of labor management } \\
\text { management of the neural network } \\
\text { where enterprise as a hub. } \\
\text { - Playing a monitoring and regulation- } \\
\text { making role }\end{array}$ \\
\hline GJK & $\begin{array}{l}\text { - GJK system is a comprehensive } \\
\text { utilization of video, network, } \\
\text { communications and other advanced } \\
\text { technology to achieve a control of } \\
\text { scientific and technological means. } \\
\text { - Its aim is to realize the real-time } \\
\text { management and supervision of the } \\
\text { construction site. } \\
\text { - GJK standardizes management } \\
\text { behavior, improves management } \\
\text { efficiency and improves the quality of } \\
\text { the entire construction process } \\
\text { management. }\end{array}$ & $\begin{array}{l}\text { - Real-time video monitoring; } \\
\text { - Automatic risk warning and risk } \\
\text { management,; } \\
\text { - Multidimensional analysis and } \\
\text { problem tracing system }\end{array}$ \\
\hline GLK & $\begin{array}{l}\text { - GLK aims to build an efficient and } \\
\text { collaborative management information } \\
\text { platform which consists of six } \\
\text { subsystems: communication } \\
\text { management, document management, } \\
\text { information dissemination, }\end{array}$ & $\begin{array}{l}\text { - Providing the various information and } \\
\text { dealing with real-time management on } \\
\text { smart phones at anytime, anywhere; } \\
\text { - Readily access to information, mobile } \\
\text { collaboration,; }\end{array}$ \\
\hline
\end{tabular}




\begin{tabular}{|l|l|l|}
\hline & $\begin{array}{l}\text { administrative affairs, job management, } \\
\text { mobile office. GLK is supported by } \\
\text { strong technical platform which } \\
\text { consists of micro-portal platform }\end{array}$ & $\begin{array}{l}\text { - Group mutual trust mechanism } \\
\text { achieving distributed deployment and } \\
\text { messages, documents, data transmission } \\
\text { exchange }\end{array}$ \\
\hline $\begin{array}{l}\text { - Guanglianda pricing function GBQ is } \\
\text { the core of the whole solution of the } \\
\text { construction budget management. } \\
\text { GBQ It mainly adopts the three modules of } \\
\text { bidding management and inventory } \\
\text { pricing to realize the bidding business } \\
\text { electronically. }\end{array}$ & $\begin{array}{l}\text { • Efficient and comprehensive pricing, } \\
\text {; Convenient group price; }\end{array}$ \\
\hline
\end{tabular}

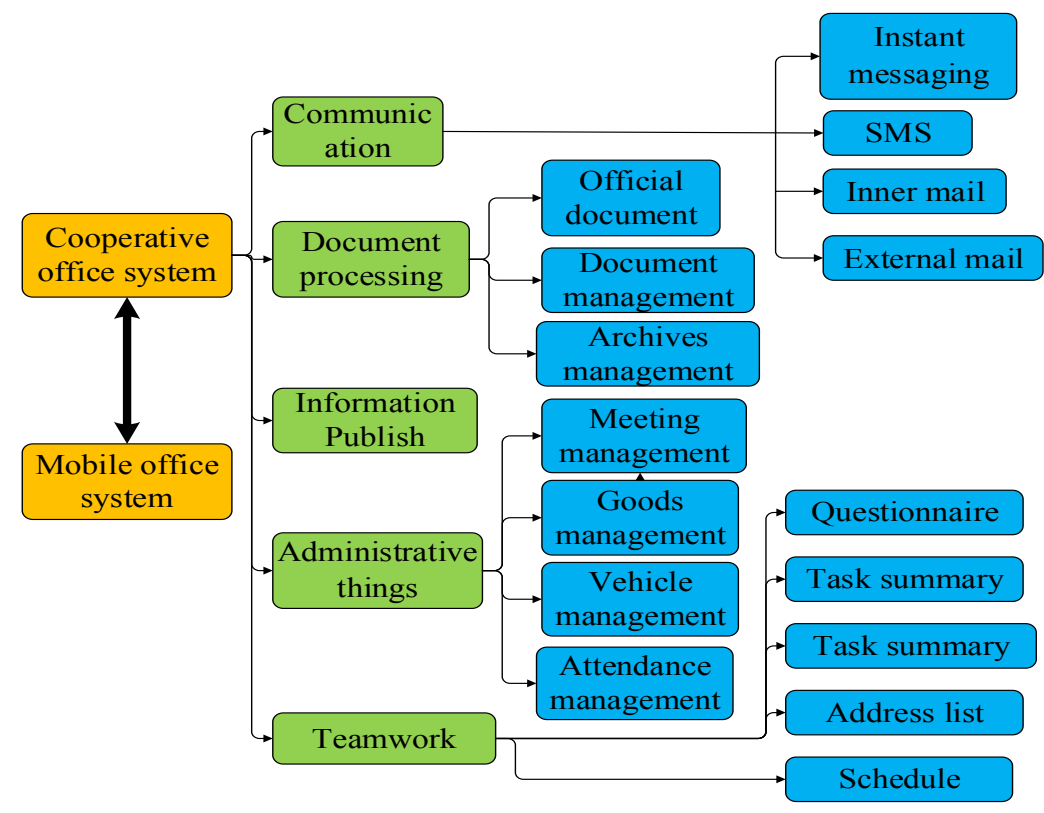

Fig. 5. Function module diagram.

\subsection{Case Analysis}

Taking the typical floor of a residential building in China as a research object, the floor plan is divided into two bays. The duration of each event is calculated with RSMeans (furtherRSMeans, United States of America, USA), and then the total construction period is determined. Use the Gunaglianda to calculate the volume of project.Specific The project volume is exported with the table form. The corresponding cost has also been derived table form.

The volume and the cost generated by the software(GBQ) of the tables, in order to make the research results more detailed, respectively, in accordance with concrete and steel; masonry; template category statistics. The volume and cost of concrete and steel show in table 6 . The volume and cost of masonry show in table 7 . The volume and cost of template show in table 8 .

Table 6. The volume and cost of Concrete and steel with Guanglianda (GBQ) 


\begin{tabular}{|c|c|c|c|c|c|}
\hline Line number & material & unit & $\begin{array}{c}\text { The volume } \\
\text { of 10-stories }\end{array}$ & $\begin{array}{c}\text { The integrated } \\
\text { unit price (Euro) }\end{array}$ & $\begin{array}{c}\text { Total cost } \\
\text { (Euro) }\end{array}$ \\
\hline 10504001004 & $\begin{array}{c}\text { Bearing wall(200mm } \\
\text { thick,C30) }\end{array}$ & Cubic meter & 251.3 & 49.17 & 12356.92 \\
\hline 10504001004 & $\begin{array}{c}\text { Internal wall(200mm } \\
\text { thick,C30) }\end{array}$ & Cubic meters & 322.41 & 49.17 & 15853.65 \\
\hline 10503002003 & Concrete beam(C30) & Cubic meters & 8.81 & 49.55 & 436.56 \\
\hline 10503002003 & $\begin{array}{c}\text { Concrete frame } \\
\text { beam(C30) }\end{array}$ & Cubic meters & 10.16 & 49.55 & 503.46 \\
\hline 10505003009 & Plates:concrete-C30 & Cubic meters & 88.39 & 49.8 & 4401.42 \\
\hline 10502002004 & $\begin{array}{c}\text { Structure } \\
\text { column:C25concrete }\end{array}$ & Cubic meters & 5.84 & 49.87 & 291.2 \\
\hline 10506001003 & Stairs:concrete-C30 & Cubic meters & 16.4 & 60.52 & 992.63 \\
\hline 10515001021 & Steel:HPB300 & ton & 1.639 & 546.83 & 896.25 \\
\hline 10515001017 & Steel:HRB400 & ton & 27.5 & 583.98 & 16059 \\
\hline
\end{tabular}

Table7. The volume and cost of masonry with Gaunglianda(GBQ)

\begin{tabular}{|c|c|c|c|c|c|}
\hline Line number & material & unit & $\begin{array}{c}\text { The } \\
\text { volume } \\
\text { of 10- } \\
\text { stories }\end{array}$ & $\begin{array}{c}\text { The integrated } \\
\text { unit } \\
\text { price(Euro) }\end{array}$ & $\begin{array}{c}\text { Total } \\
\text { cost } \\
\text { (Euro) }\end{array}$ \\
\hline 10402001001 & $\begin{array}{c}\text { Bearing wall: } 200 \text { thick } \\
\text { aerated concrete block }\end{array}$ & $\begin{array}{c}\text { Cubic } \\
\text { meters }\end{array}$ & 104.73 & 36.45 & 3817.22 \\
4
\end{tabular}

Table 8. The volume and costs of template with Guanglianda(GBQ)

\begin{tabular}{|c|c|c|c|c|c|}
\hline Line number & material & unit & $\begin{array}{c}\text { The volume } \\
\text { of 10-stories }\end{array}$ & $\begin{array}{c}\text { The integrated } \\
\text { unit price(Euro) }\end{array}$ & $\begin{array}{c}\text { Total } \\
\text { cost(Euro) }\end{array}$ \\
\hline 11702011001 & $\begin{array}{c}\text { Bearing } \\
\text { wall(200mm } \\
\text { thick,C30) }\end{array}$ & $\begin{array}{l}\text { square } \\
\text { meters }\end{array}$ & 518 & 2.95 & 1526.84 \\
\hline 11702011001 & $\begin{array}{c}\text { Internal } \\
\text { wall(200mm } \\
\text { thick,C30) }\end{array}$ & $\begin{array}{l}\text { square } \\
\text { meters }\end{array}$ & 641.31 & 2.95 & 1890.22 \\
\hline 11702011001 & $\begin{array}{c}\text { Concrete } \\
\text { beam(C30) }\end{array}$ & $\begin{array}{l}\text { square } \\
\text { meters }\end{array}$ & 106.56 & 2.95 & 314.04 \\
\hline 11702006001 & $\begin{array}{c}\text { Concrete frame } \\
\text { beam(C30) }\end{array}$ & $\begin{array}{l}\text { square } \\
\text { meters }\end{array}$ & 126 & 7.74 & 975.25 \\
\hline 11702016001 & $\begin{array}{c}\text { Plates:concrete } \\
\text {-C30 }\end{array}$ & $\begin{array}{l}\text { square } \\
\text { meters }\end{array}$ & 737.5 & 6.78 & 5000.83 \\
\hline 11702003001 & $\begin{array}{c}\text { Structure } \\
\text { column:C25 }\end{array}$ & $\begin{array}{c}\text { square } \\
\text { meters }\end{array}$ & 85.2 & 11.30 & 962.37 \\
\hline
\end{tabular}


Table 9. Table of comprehensive unit price analysis with Guanglianda(GBQ)

\begin{tabular}{|c|c|c|c|c|c|c|c|c|c|c|c|}
\hline \multirow{2}{*}{ 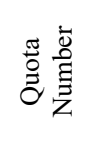 } & \multirow{2}{*}{ 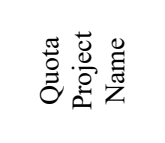 } & \multirow{2}{*}{ 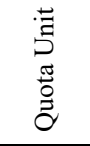 } & \multirow{2}{*}{ 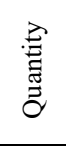 } & \multicolumn{4}{|c|}{ Unit Price } & \multicolumn{4}{|c|}{ Total Price } \\
\hline & & & & $\mathrm{X} 1$ & $\mathrm{X} 2$ & $\mathrm{X} 3$ & $\mathrm{X} 4$ & $\mathrm{X} 1$ & $\mathrm{X} 2$ & $\mathrm{X} 3$ & $\mathrm{X} 4$ \\
\hline A4-206 & $\begin{array}{c}\text { Pump Pre- } \\
\text { mixed } \\
\text { Concrete } \\
\text { Steel } \\
\text { Template } \\
\text { Wall }\end{array}$ & $\begin{array}{l}\text { Cubic } \\
\text { meters }\end{array}$ & 0.1 & 15 & 390 & 2 & 38 & 2 & 39 & 0.2 & 4 \\
\hline A4-198 & $\begin{array}{l}\text { Pump Pre- } \\
\text { mixed } \\
\text { Concrete } \\
\text { Single Beam } \\
\end{array}$ & $\begin{array}{l}\text { Cubic } \\
\text { meters }\end{array}$ & 0.009 & 14 & 393 & 2 & 39 & 1 & 39 & 0.2 & 4 \\
\hline A4-210 & $\begin{array}{c}\text { Pump Pre- } \\
\text { mixed } \\
\text { Concrete } \\
\text { plate } \\
\end{array}$ & $\begin{array}{l}\text { Cubic } \\
\text { meters }\end{array}$ & 0.1 & 16 & 393 & 2 & 39 & 2 & 39 & 0.2 & 4 \\
\hline A4-195 & $\begin{array}{c}\text { Pump Pre- } \\
\text { mixed } \\
\text { Concrete } \\
\text { structural } \\
\text { columns }\end{array}$ & $\begin{array}{l}\text { Cubic } \\
\text { meters }\end{array}$ & 0.1 & 44 & 367 & 2 & 40 & 4 & 37 & 0.2 & 4 \\
\hline A4-215 & $\begin{array}{c}\text { Mixed } \\
\text { Concrete } \\
\text { straight stairs }\end{array}$ & $\begin{array}{l}\text { square } \\
\text { meters }\end{array}$ & 0.1 & 10 & 97 & 1 & 10 & 1 & 10 & 0.1 & 1 \\
\hline A4-415 & $\begin{array}{l}\text { Cast-in-situ } \\
\text { components } \\
\text { round bar }\end{array}$ & ton & 1 & 140 & 334 & 8 & 70 & 140 & 334 & 8 & 70 \\
\hline $\begin{array}{c}\mathrm{A} 4-418 \\
\mathrm{R} * 1.1\end{array}$ & $\begin{array}{c}\text { Cast-in-place } \\
\text { components } \\
\text { rebar }\end{array}$ & ton & 1 & 164 & 340 & 10 & 76 & 164 & 340 & 10 & 76 \\
\hline A3-49 & $\begin{array}{c}\text { Fly ash } \\
\text { Areated } \\
\text { concrete } \\
\text { block wall }\end{array}$ & $\begin{array}{l}\text { Cubic } \\
\text { meters }\end{array}$ & 0.1 & 71 & 259 & 4 & 34 & 7 & 26 & 0.4 & 3 \\
\hline A3-20 & Plasted brick & $\begin{array}{l}\text { Cubic } \\
\text { meters }\end{array}$ & 0.1 & 141 & 286 & 6 & 42 & 14 & 29 & 0.6 & 4 \\
\hline A12-62 & $\begin{array}{l}\text { Template of } \\
\text { cast-in-situ } \\
\text { concrete steel } \\
\text { template wall }\end{array}$ & $\begin{array}{l}\text { square } \\
\text { meters }\end{array}$ & 0.01 & 98 & 117 & 54 & 29 & 1 & 1.2 & 0.5 & 0.3 \\
\hline A12-46 & $\begin{array}{l}\text { Template of } \\
\text { cast-in-situ } \\
\text { concrete }\end{array}$ & $\begin{array}{l}\text { square } \\
\text { meters }\end{array}$ & 0.01 & 218 & 435 & 64 & 65 & 2 & 4 & 0.6 & 0.6 \\
\hline
\end{tabular}

X1-Labort cost; X2-Material Cost; X3-Mechanical Cost; X4-Management Cost and Profit.

Then, the construction schedule was constructed with the critical path method [15]. the schedule will show in Guanglianda. 


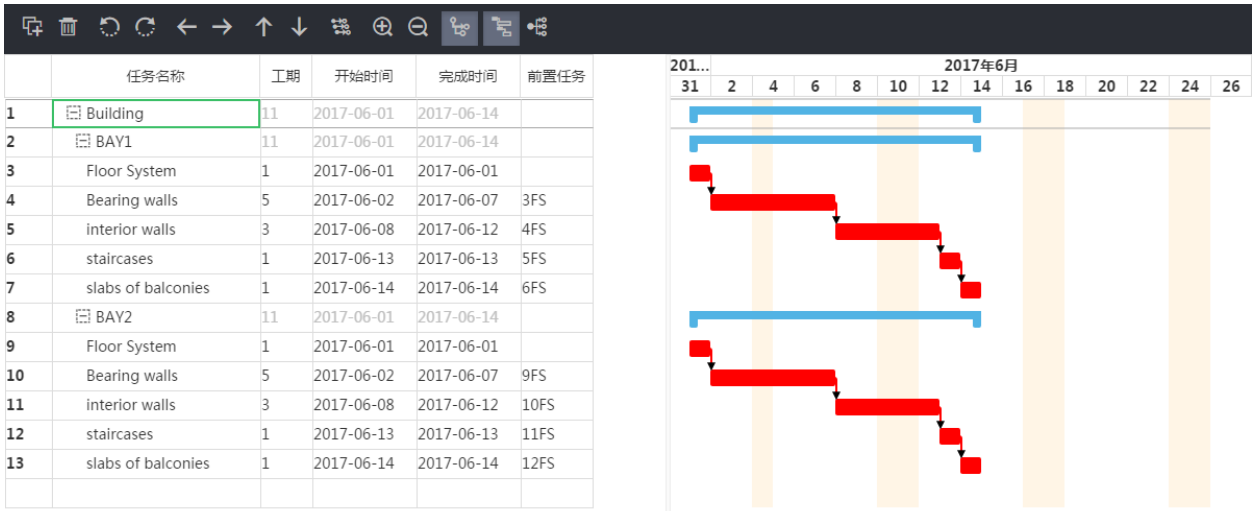

Fig.6. Schedule of construction (one typical floor of a building) and technical complex with the application of the RSMeans framework created by Guanglianda

Input a residential typical floor plan in Guanglianda (GCL), through the choice of building materials, could calculate the volume of the work.

\section{Results}

There are numerous problems facing today's construction process management. Many of these are a result of inappropriate pre-preparation issues including budget estimation, workforce considerations, safety, etc. Successful construction process management insures the completion of the construction project in time, within budget, and to do the project specifications[2].In addition, the planning for labors, construction materials, machinery, including cranes, and others should be made effectively, safely and economically[16]. Process management is the core of a successful construction project, including management model propose, implementation, construction site inspection and supervision in the process[3]. If one part of the whole chain falls, the project could be largely influenced even be suspended. The development of the process management is the vital part of the every single project. However, in actual construction, construction units that will always be perfunctory[3], fail to take it seriously and not realize that the progress of the implementation plan is the vital core of the plan, which results in ineffective implementation of the situation[17]. In addition, expenditures of time, money and resources, including human and material, are wasted each year because ineffective or failed balance of time, cost and quality[6]. In the construction process management, the time management can effectively be advanced if the budget is estimated high between the time and cost[18]. To improve speed of the construction, in another word, to improve time efficiency, the quality side is likely and largely to be influenced and eliminated. Quality and cost, as long as problems of the quality arise, you need funds to remedy; the quality will decline if funds shrink[3]. So the relationship between the three needs proper management to control in a process management model. The comparison between Nevisworks and Guanglianda shows that Guanglianda is more efficient and economic in construction management[20]. Guanglianda's competence of threedimension, real-time and intelligent management provides companies accurate reference for decision-making. According to the 2012-2018 The Precast Analysis Report of Chinese Construction Management Industry, the number of enterprises that use software of Guanglianda is already nearly $60 \%$, some of non-Guanglianda users around $40 \%$ of 
construction companies in China are positive about the future of Guanglianda due to its high efficiency and commercial benefits[21].

\section{Conclusion}

This paper compared the main use of Revit in 3D modeling (design stage), the use of Guanglianda in the whole process of construction management. This paper then proposed possible ways of application of Guanglianda and Chinese project management methods into Russia after the researches on the different functions of Guanglianda.

1.It is confirmed that the most effective, economic and fast way of management and construction is the combine method of BIM technology, such as Revit, and Chinese Guanglianda platform.

2. We have found that the functional parts of Guanglianda are the contributing facts that Chinese construction has been conducted in an unprecedented speed.

3. When researching on the development of BIM technology and Guanglianda construction, we still find there are some restraints considering statics, construction cases, etc. In order to apply Chinese Guanglianda platform and project management methods into European construction process, this is an open area for further research.

\section{References}

1. China City Press, China construction industry information development report, (2004)

2. J. Xu, Research on application of BIM 5D Technology in central grand project, school of management and engineering. Journal of Zhejiang University. (2016)

3. Z. Xinsheng, using BIM techology to carry out life cycle application to enhance he quality of project [J], Focusing on information, 31(6): 20-24 (2013)

4. J. Zhang, Construction resource dynamic management and real-time monitoring based on 4D-BIM [J], Construction Technology.(2011)

5. L. Yong, Construction project BIM prediction method research [D], Journal of Wuhan University of Technology, (2014)

6. LIU xian-wei, GAO Hong-gang, WANG Fu-sheng, Application value and implement of BIM in construction field [J], Construction Technology, (2012)

7. LIU Zhao-qiu,WANG fu-lei, LI-Yun-gui, BIM construction and its Value Analysis in design and Construction [J], Acta Scientiae Scientia Sinica, (2014)

8. Unified standard for building information modeling, (2017)

9. L. S. Chin, et al, The practice of time management on construction project, the 5th International Conference of Euro Asia Civil Engineering Forum (EACEF-5)

10. X. Li, et al, Research on Construction Schedule Management Based on BIM Technology, 13th Global Congress on Manufacturing and Management, GCMM (2016)

11. A. Izmailov, et al, Project management using the buffers of time and resources, 12th International Strategic Management Conference, ISMC, (2016)

12. K. Zhou, Autodesk Revit Building, Architecture Journal, (2017)

13. H. Mallawaarachchi, S.Senaratne, Importance of Quality for Construction Project Success, 6th International Conference on Structural Engineering and Construction Management (2015)

14. CHAU K W, ANSON M, ZHANG J P. 4D dynamic construction management and visualization software, Automation in Construction, (2005) 
15. M. Romanovich, et al, International Scientific Conference Energy Management of Municipal Transportation Facilities and Transport EMMFT 2017 pp265 - 272. (2017)

16. KYMMELL W. Building information modeling: planning and managing construction projects with 4D CAD and simulations [M]. New York: McGraw-Hill, (2008)

17. LI H, CHAN N, HUANG T, et al. Optimizing construction planning schedules by virtual prototyping enable resource analysis. Automation in Construction, (2009)

18. GOEDERT J D, MEADATI P. Integrating construction process documentation into building information modeling. Journal of Construction Engineering and Management, (2008)

19. E. C. Teicholz et al,. BIM Handbook: A Guide to Building Information Modeling for Owners, Managers, Designers, Engineers and Contractors [M]. NY John Wiley and Sons, (2008)

20. Computer Integrated Construction Research Group, Building Information Modeling Execution Planning Guide Version 2, (2010)

21. R.Jardim - Goncalves. Building information modeling and inter operation. Automation in Construction, (2010) 